Open Access

\title{
Preservice science teachers' emerging pedagogy of mobile game integration: a tale of two cohorts improvement study
}

\author{
Phattaraporn Pondee ${ }^{1}$, Patcharin Panjaburee ${ }^{2}$ and Niwat Srisawasdi ${ }^{1^{*}}$ (D)
}

\author{
* Correspondence: niwsri@kku.ac.th \\ ${ }^{1}$ Faculty of Education, Khon Kaen \\ University, Khon Kaen, Thailand \\ Full list of author information is \\ available at the end of the article
}

\begin{abstract}
In the context of the current teacher education program in Thailand, Technology Pedagogical and Content Knowledge (TPACK) framework is formally recognized as essential qualities of knowledge for a highly qualified preservice teacher in today's education. TPACK has been attracted to educational researchers for preparing preservice science teachers nationwide. In this study, TPACK was employed for restructuring a preservice science teacher education course with mobile game technology, which was offered in two consecutive semesters with a total enrollment of 115 student teachers in the first cohort and 94 student teachers in the second cohort. A pedagogic module of Mobile Game-based Inquiry Learning in Science (MGILS) has been designed and created in two settings, a usual separated and integrated case-based TPACK support module, and then implemented with the first and second cohort respectively in general science teacher education program at a Rajabhat University of Thailand. They were measured TPACK in terms of four constructs, namely, (a) technological knowledge (TK), (b) technological content knowledge (TCK), (c) technological pedagogical knowledge (TPK), and (d) technological pedagogical content knowledge (TPCK). Considering both qualitative and quantitative data analysis from two cohorts, the results showed preservice science teachers' incremental TPACK improvement from the implementation of the usual separated and integrated case-based TPACK support module of MGILS. Based on the results of MGILS intervention, it seems to indicate the alleged superiority of the integrated case-based TPACK support over the usual separated TPACK support. The deficits in the use of MGILS module are identified, and possible improvements to enhance TPACK in the mobile game are proposed.
\end{abstract}

Keywords: TPACK, Mobile learning, Digital game, Ubiquitous technology, Preservice teacher
( ) The Author(s). 2021, corrected publication 2021. Open Access This article is licensed under a Creative Commons Attribution 4.0 International License, which permits use, sharing, adaptation, distribution and reproduction in any medium or format, as long as you give appropriate credit to the original author(s) and the source, provide a link to the Creative Commons licence, and indicate if changes were made. The images or other third party material in this article are included in the article's Creative Commons licence, unless indicated otherwise in a credit line to the material. If material is not included in the article's Creative Commons licence and your intended use is not permitted by statutory regulation or exceeds the permitted use, you will need to obtain permission directly from the copyright holder. To view a copy of this licence, visit http://creativecommons.org/licenses/by/4.0/. 


\section{Introduction}

Currently, mobile technologies, such as smartphones and tablet computers, have been increasingly recognized to apply to educational settings for improving the quality of the learning process mediated by portable devices and wireless networked technologies. Besides, applications of mobile technologies have been recognized as mobile learning or m-learning. Scholars have mentioned that mobile learning or m-learning is an enhanced instruction with "anytime, anywhere" situation perspectives and have grown rapidly in educational activities in many subject areas (McQuiggan et al., 2015; Newhouse et al., 2006; Srisawasdi, Burnterm, Pondee, 2018). To take the benefits of the manifold opportunities of mobile technology into account, the learning environment with mobile games is a frequency format used (Schmitz et al., 2015). That is to say, the incorporation of mobile learning into gaming has been an increase in the adaptation to the educational context as part of improving learning enjoyment and motivation (Hakak et al., 2019). Nowadays, mobile game-based learning in school education has become a popular research topic since it allows students to not only boost their learning in an enjoyable way (Chen, Liu, \& Huang, 2019; Huizenga, Admiraal, ten Dam, \& Voogt, 2019) but also enhances their motivation (Daungcharone, Panjaburee, \& Thongkoo, 2019; Gamlo, 2019) and content understanding and process skills (Hussein et al., 2019). However, it seems, in the context of Thailand, that mobile games are perceived only as a means for recreation and entertainment. Vate-U-Lan (2015) mentioned a study report in Thailand that the word "games and entertainment" was the most searched keyword of any search engine. Moreover, Momypedia (2013) reported that Thai children spent approximately 80 percent of their time using computers to play digital games, and game-playing seems to be the most favored activity of Thai youths reported by the Ministry of Information and Communication Technology of Thailand (Vate-U-Lan, 2015). According to the evidence, playing computer games has become a normal recreation and entertainment part of Thai children and adolescents' routines. This could also bring today teachers' perceptions toward digital or mobile games falling into only as a means for recreation and entertainment and not for learning. Consequently, many schools and many teachers oppose the use of smartphones at school because mobile games are distractive and therefore reduce students' attention and concentration in class (Baker et al., 2012; Thomas, O'bannon \& Britt, 2014). This situation might cause them to lose their ability to control the class (Sad \& Goktas, 2014). In other words, the teachers have less ability in examining how to use mobile games to support their teaching and learning pedagogies and to transfer the content for establishing the informed teaching decisions. Thus, preservice teachers require a specific kind of knowledge to appropriately design meaningful learning experiences with mobile games and pedagogically implement mobile games in their teaching, which is, specifically, technological pedagogical and content knowledge (TPACK).

The TPACK framework builds on Shulman's (1986) construct of pedagogical content knowledge (PCK) to include technological knowledge as another essential part of the professional teaching knowledge, and it was first proposed by Mishra and Koehler (2006). Current educational studies revolved around the employment of TPACK framework to design technology-integration courses in the context of teacher education (Janssen, Knoef, \& Lazonder, 2019). In the community of science teacher education development, the current reform expects preservice and in-service science teachers to 
effectively integrate digital technology, such as a mobile game, and inquiry-based teaching into their instruction (Srisawasdi, 2014). In an effort with the reform, Hsu, Liang, Chai, \& Tsai, (2013) proposed an adapted TPACK framework called technological pedagogical and content knowledge-games (TPACK-G) as a guideline to improve inservice preschool teachers' professional development for teaching with game technology. The results indicated that game pedagogical knowledge (GPK) and game pedagogical content knowledge (GPCK) are more specific knowledge building on the fundamental knowledge, game knowledge (GK). To enhance the development of GPK and GPCK, learners, first of all, are required to possess sufficient GK. In the study, they found that the teachers rarely require such knowledge that uses games to represent subject matter knowledge while excluding the element of pedagogy. Moreover, Hsu, Liang, and $\mathrm{Su}$ (2015) revised the implementation of TPACK-G for 49 in-service preschool teachers. It was found that instruction with game knowledge tended to promote higher competencies in-game knowledge and game pedagogical content knowledge to teachers more than that with game pedagogical knowledge first. In the context of preservice science teacher development, preparing preservice science teachers for mobile game integration is a complex and challenging job for teacher educators. To overcome this obstacle, Smarkola (2008) has suggested training preservice teachers in educational technology, in a particular implementation of the mobile game, when they were in the beginning stage of teacher education. Moreover, it is suggested that the teachers, who can know using the mobile game technologies to create science teaching and learning activities, could gain highquality science teaching competencies (Becker, 2007; Srisawasdi, Bunterm, \& Pondee, 2018). However, preservice science teacher's supports and training for TPACK of the mobile game in science learning have been the least explored topics in preservice science teacher education research. As such, the purpose of this study was to evaluate the effects of a pedagogic module of mobile game-based inquiry learning in science (MGILS) designing based on TPACK framework and assess preservice science teachers' TPACK in the pedagogical application of mobile game-based science inquiry learning.

\section{Literature review}

A basis for science teacher education movement and preservice science teacher support, technological pedagogical and content knowledge (TPACK)

In recent years, a well-respected professional teaching knowledge model that depicts what professional teachers should possess is the technological, pedagogical and content knowledge (TPACK) framework. This framework builds on Shulman's (1986) construct of pedagogical content knowledge (PCK) to include technological knowledge as another essential part of the professional teaching knowledge, and it was first proposed by Mishra and Koehler (2006). This framework acknowledges the interrelations among the three kinds of knowledge addressed: technology, pedagogy, and content (Thompson \& Mishra, 2007), and it was introduced to the educational research community as a theoretical model for understanding teacher essential knowledge required for effective technology integration in teaching (Koehler \& Mishra, 2005, 2008; Mishra \& Koehler, 2006). The TPACK framework is visualized in Fig. 1.

Figure 1 shows the integration among three core categories of knowledge, such as pedagogical knowledge (PK), content knowledge (CK), and technological knowledge 


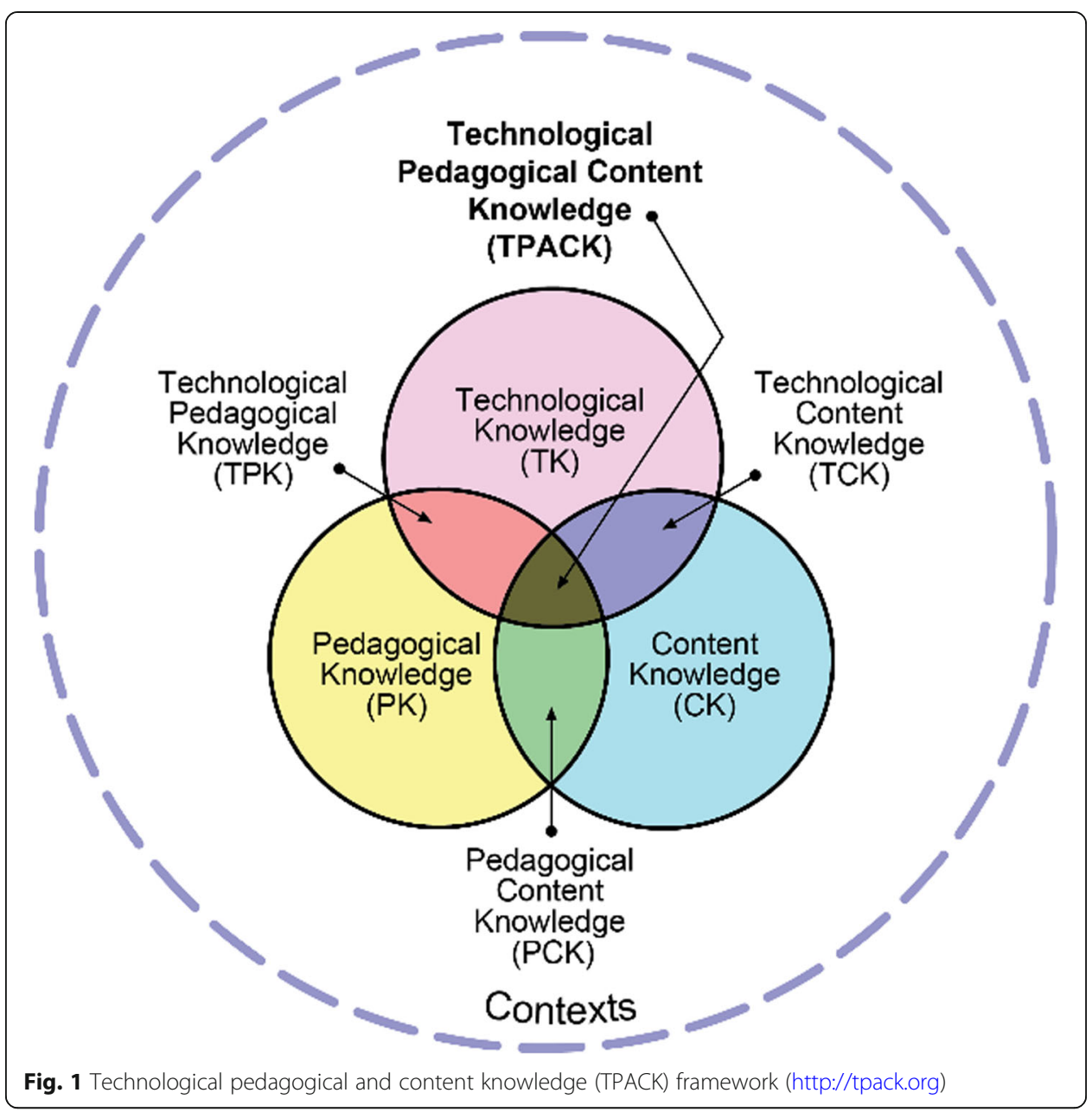

(TK) to forming four intersections of knowledge, such as pedagogical content knowledge (PCK), technological pedagogical knowledge (TPK), technological content knowledge (TCK), and technological pedagogical content knowledge (TPCK). Therefore, there are seven essential components of knowledge providing for teachers who prefer to use or apply technology in their classrooms. PK refers to knowledge about teaching and learning practices, strategies, and learning tasks used to deliver subject content to students. CK refers to knowledge or understanding about the particular subject matter or learning content learned and taught in the classrooms. TK refers to knowledge of the features of the technologies and particular skills to use such technologies. PCK, which is knowledge integration between PK and CK, explains about knowledge of particular teaching methods concerning subject matter content. TPK, which is knowledge integration between TK and PK, explains knowledge about using technologies to plan and monitor the teaching and learning process, to construct or transform the different forms of subject matter representations, and to facilitate the teaching and learning process. TCK, which is knowledge integration between TK and CK, explains knowledge for selecting appropriate technology to present the subject matter taught in the learning activities. TPACK, which is knowledge integration among TK, PK, and CK, explains knowledge for selecting appropriate technology to implement teaching and learning methods or strategies for the different representations of subject 
matter content. In other words, TPACK has been recognized as a framework to professional development or teacher education in which a teacher is trained to have knowledge or ability to designing learning activities to present subject matter content with an appropriate technological tool (Koehler \& Mishra, 2008; Mishra \& Koehler, 2006, Niess, 2005; Niess et al., 2006, 2009).

Current educational studies that employed the TPACK framework were mainly conducted in the context of teacher education (Janssen, Knoef, \& Lazonder, 2019). Most of these studies intended to design and develop technology-integration courses that aimed to foster preservice teachers' development of TPACK (Voogt et al., 2013). In the light of science teacher education development, the efforts of current science education reforms expect science teachers to integrate digital technology and inquiry-based teaching into their instruction (Srisawasdi, 2014). Current science teacher education reforms are recognizing the importance of TPACK for preservice science teachers and the preservice science teachers are targeted to improve their teaching proficiency based on the implementation of TPACK as an integrative framework of instructional interventions (Srisawasdi \& Panjaburee, 2014). However, there was still a limited number of study targeted the development of teaching intervention to foster preservice science teachers' TPACK. To give examples, Cetin-Dindar et al. (2018) designed a pedagogic course focusing the learning how to integrate simulations, animations, instructional games, datalogging, virtual labs, and virtual field trips into chemistry instruction, and then implemented it with 17 preservice chemistry teachers. They interacted with the course for one semester and the result revealed that the preservice chemistry teachers' TPACK improved partially on some components. Similarly, Srisawasdi, Pondee, and Bunterm (2018) designed TPACK-oriented coursework, as shown in Fig. 2 (left), and implemented a technology-integrated pedagogy module of mobile laboratory learning in science (MLLS) for improving 119 pre-service science teachers' TPACK. They participated in the MLLS module in 4 weeks. It was found that the MLLS module could foster pre-service science teachers to gain better levels of TK, TCK, TPK, and TPACK.

To promote preservice science teachers' TPACK regarding computerized laboratory environment in physics teaching, Srisawasdi (2014) adapted the TPACK framework to address physics teaching competencies, as shown in Fig. 2 (right), and designed an alignment of pedagogic courses for the preservice science teachers' TPACK development. A series of pedagogic courses have been implemented within 3 years and the results revealed that the preservice physics teachers had relative teaching performance in which technology and pedagogy were combined to facilitate the learning of specific

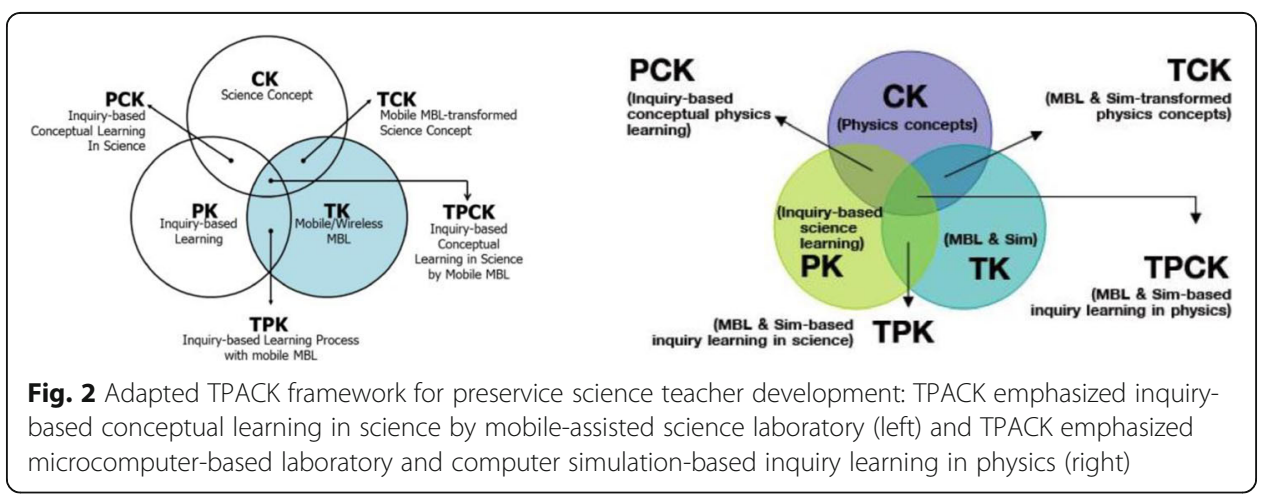


physics concepts. Moreover, Chittleborough (2014) reported a result of 28 preservice chemistry teachers' TPACK development after they undertook a chemistry curriculum studies unit that adopted a technological focus. It revealed that the teachers were able to explain the features of technology in teaching and learning and to increase skills for performing a variety of technologies. Moreover, some of their students had doubts when schools did not provide technological resources to support learning activities. Janssen \& Lazonder (2016) also reported an experimental study of using pedagogical and content support to foster preservice biology teachers' TPACK in designing an effective lesson plan. In this study, 54 pre-service biology teachers were divided into two groups and each group was asked to participate in the different instructional interventions. The experimental results showed that the preservice teachers who followed the integrated support had more integrated pedagogical and content-related justifications and higher quality lesson plans than those who received separate support.

As seen in those previous studies, it is clear that the TPACK framework plays a crucial role in proposing the development of a science teacher education program. It is also recognized as essential knowledge to fostering the preservice science teachers to gain more teaching competencies in terms of pedagogically presenting science content with appropriate technologies. Besides, Hsu et al. (2013) mentioned that the current TPACK studies are inclined to treat technology in a general manner because the general approach to technology may not be able to provide adequate guidelines to improve teacher preparation for teaching with emerging and unique technology, such as games. To date, digital and mobile game-based learning has been receiving great attention from and applying by educators, researchers, and practitioners, and its positive impacts on students' academic learning outcomes have been reported (Hsu, Liang, Chuang, Chai, \& Tsai 2020). In terms of the complexity of digital and mobile game technology integration, science teachers require an understanding of the deep connections of the three primary components (i.e., technological knowledge of the mobile game, pedagogical knowledge, and science content knowledge). As such, there is a clear need to promote preservice science teachers' knowledge about the teaching science with games or TPACK in mobile game-based science learning.

Digital and mobile game-based learning in school science education

Digital games have been gaining tremendous interest in teaching and learning in the twenty-first-century education. In recent years, implementing digital game technology in school education is recognizing increasingly as a pedagogical tool to induce students' learning interest and also enhance their learning effectiveness in science. Digital gamebased learning (DGBL) refers to the learning approach that incorporates educational content for learning into digital games, and this approach has been recognized as an effective way to situate students into authentic learning contexts (Chang \& Hwang, 2019). In this regard, the implementation of these kinds of pedagogical tools can motivate science teachers because they need to transform the teaching-learning process to being almost a recreational activity (Antunes, Pacheco, \& Giovanela, 2012).

In the particular context of school science education, DGBL has been perceived as an engaging teaching approach to foster elementary school students' learning, and it showed promising potential in the area of science content understanding and process 
skills, and role-playing game (RPG) was the most popular game genre for learning (Hussein et al., 2019). For instance, Hsu \& Tsai (2013) examined the effects of an educational computer game with and without self-explanation prompts on science learning of light and shadow concepts. In this study, a total of 58 third graders recruited from a primary school in northern Taiwan involved to interact with the intervention, and the results showed that students who played the game with self-explanation features did not outperform those who played the game without any prompts. Besides, Sung \& Hwang (2017) created the repertory grid-based educational game (REG) to facilitate students' knowledge sharing and organizing during the DGBL process. In this study, the results showed that they expressed significantly more aggressive learning behavioral patterns during the DGBL process.

With the pedagogical potential of DGBL, this approach has also been examined its effectiveness relating to instructional methods (gameplay design) and science game variants enriched with mechanisms (game's mechanism design) by Tsai \& Tsai (2020). The results of this study showed that students significantly benefit from the DGBL in science in terms of scientific knowledge, and its learning and gaming mechanisms play key roles in the significant learning gains. To give an example, Hwang et al. (2012) developed a personalized RPG based on students' learning styles and then implemented it with 46 fifth graders of an elementary school in Taiwan. The results showed that the personalized RPG learning approach not only promotes learning motivation but also improves the learning achievements of the students. Moreover, Sung et al. (2018) developed a 3D experiential game facilitating students' deep-strategy learning behaviors and positive inquiry learning performances in science, and the game has been implemented with 53 sixth graders from an elementary school in Taiwan. They interacted with the 3D experiential gaming system in a geoscience course, and the results showed that they gained better learning achievements, problem-solving tendency, deep learning strategies, and deep learning motive than those who learned with the conventional technology-enhanced learning approach.

Over the past decade, researchers have attempted to understand the application of DGBL in the context of the mobile technology-supported learning environment. The incorporation of mobile learning and digital gaming has been gradually increasing in the context of educational improvement (Hakak et al., 2019). Currently, the development of mobile learning games is known by the term "mobile game-based learning" (MGBL), which refers to the use of mobile games incorporating educational value for learning or gaming software applications designed for learning purposes through mobile devices (Troussasa, Krouskaa, \& Sgouropoulou, 2020), constitutes a popular issue in the scientific literature of technology-enhanced learning. For example, Hwang et al. (2015) explored the effectiveness of augmented reality-based learning games on students' learning achievements and attitudes in an instructional context real-world investigation. In this study, 57 fifth-graders received the 90-min intervention during studying in an elementary school ecology course. The results showed that the augmented reality-based gaming approach can improve their learning performance on the field trip.

However, the MGBL was rarely studied in school science education in the context of Thailand (e.g., Komalawardhana \& Panjaburee, 2018; Komalawardhana, Panjaburee, \& Srisawasdi, 2021; Meekaew \& Ketpichainarong, 2018; Srisawasdi \& Panjaburee, 2019). 
As such it is plenty of room to develop effective MGBL and also investigate its learning effectiveness for students at all education levels. Moreover, successful integration of MGBL into school science requires one to focus on the integrative interplay of mobile game knowledge, pedagogical knowledge, and science content knowledge, and the TPACK framework would be able to serve as a pedagogical platform for a professional science teacher. In science class, the technology of mobile games can be potential means of not only promoting learning engagement but also enlarging learning opportunities (Hsu et al., 2013). Besides, the inadequacy of teacher preparation programs treating MGBL in science and TPACK in isolation is a growing concern among educators, researchers, and practitioners. Moreover, a particular context of teaching with games might not be able to use general guidelines for teaching with general technology to gain effective teaching (Hsu et al., 2020). The lack of specificity could reduce the usefulness of the TPACK framework in terms of promoting TPACK comprehension and evaluating TPACK in a specific context (Willermark, 2017). Therefore, effective interventions to improve preservice science teachers' professional knowledge to leverage their TPACK in mobile gaming environments, and specific guidelines for MGBL in science in their teaching should be studied.

\section{Context of the study}

With the advancement of educational technology and a wide range of digital tools in education over the last two decades, educational researchers have made significant advancements in theorizing, designing, and repurposing digital games for learning in school education (Foster \& Shah, 2020; Kafai \& Burke, 2015). As digital game technology is an integral part of modern teaching and learning processes, teacher-candidates in teacher preparation programs need to fully achieve a new set of technology-pedagogy competencies through ongoing and timely supports provided by teacher education institutions. In this regard, the need to promote adequate digital game-based pedagogy training of future teachers has led the researchers to design and develop a pedagogic course associated with digital game technology integration in teacher education programs. As such, this study emerges from an understanding of educational technology, teacher education, and science education where the digital games should be situated in a flexible framework of knowledge of content, pedagogy, and technology for science teacher preparation and professional development. By following a TPACK model as an intervention approach in this study, the researchers applied those mentioned understanding to create a strategic technologypedagogy interaction learning module emphasizing the pedagogical application of digital or mobile game-based inquiry learning approach for science content. Figure 3 presents an integrative framework of essential knowledge for using the digital or mobile games in inquiry-based science learning for promoting the learning of science-oriented concepts.

With applications of TPACK framework, this paper focuses only on the four categories associated with technology. That is to say, TK, TCK, TPK, and TPACK are particularly considered, as shown in Fig. 3. Those categories are strongly interrelated regarding their common denominator. In the integrative framework, TK refers to technical understanding and skills required to interact and manipulate the digital or mobile games to achieve its goal. TCK refers to technological competencies or knowledge of digital or mobile games to present particular content of science. TPK focuses on instructional competencies in which 


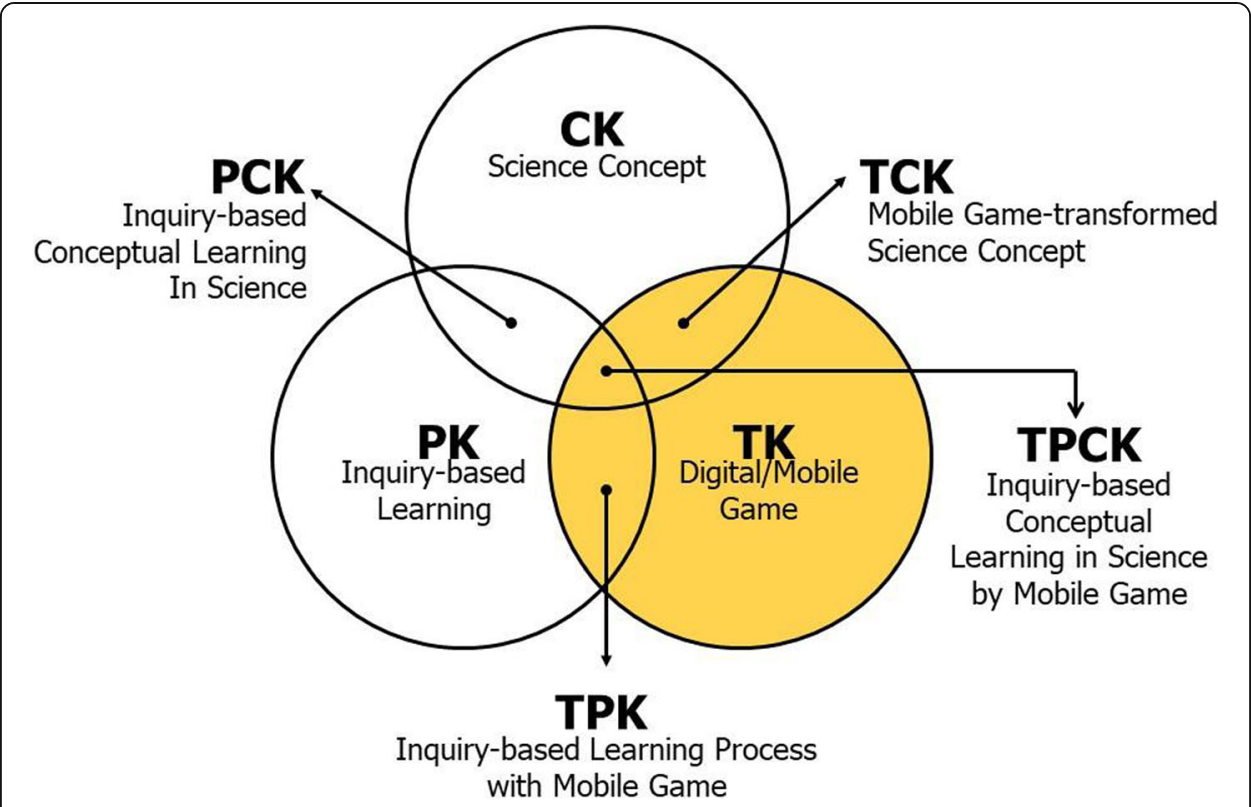

Fig. 3 An integrative framework of TPACK emphasized the interaction of digital/mobile game, inquirybased learning, and science concept (Adapted from Mishra \& Koehler, 2006)

the teachers can enhance science teaching and learning strategies with the incorporation of the digital or mobile games in the enactment of the curriculum. Finally, TPCK or TPACK represents the set of instructional competencies regarding the use of digital or mobile game to support content-specific pedagogical strategies (e.g., the use of the digital or mobile games to facilitate inquiry-based learning in science). To do this, the researchers developed an educational mobile game as a pedagogical tool and embedded the game into a pedagogical basis of an open-inquiry learning approach. Then, a pedagogic training module of mobile game-based inquiry learning in science (MGILS) has been designed regarding the proposed TPACK framework.

This study has been conducted with two cohorts of preservice science teachers aimed at improving their TPACK regarding technological integration ability and also reflecting the pedagogical design of a teacher preparation course. The ultimate purpose was to promote a well-design teaching practice focusing on the use of the mobile games in school science classes for preparing high-qualified preservice science teachers in today's teacher education. The results of this study will provide baseline practice in teacher preparation for the design of or renovating new pedagogic course emphasizing how to use the mobile game for enhancing science learning with inquiry and explain how TPACK for mobile game-based inquiry learning in science may be reflected in future teacher education curriculum or preservice teacher's instruction. The primary research question in this study is as follows:

1) What are preservice science teachers' TPACK of inquiry-based conceptual learning in science by the mobile game before and after an implementation of the usual technology-oriented pedagogic module of mobile game-based inquiry learning in science (MGILS)? 
2) Is there a significant difference between preservice science teachers' TPACK before and after implementation of the revised, case-based approach, MGILS?

Most of the studies in the literature have shown preservice science teachers' TPACK levels descriptively or have presented information about their development of TPACK only on survey findings. However, there have been very few research studies that have analyzed preservice science teachers' development of TPACK that have included both quantitative and qualitative data and indicated both descriptive and inferential information in statistics.

\section{Methods}

\section{Study participants}

This study employed a pre-experimental research design that involved two phases of data collection-pre-and post-intervention. The participants in this study are defined as two science pre-service teacher cohort groups from 2018-2019. The study participants consisted of 209 pre-service science teachers, the fourth-year students in a five-year undergraduate teacher education program in a public teacher former university located in the northeastern region of Thailand. They were 166 (79.4\%) females and 43 males (20.6\%) divided into two cohorts, named cohort 1 and cohort 2, and the age between 21 and 22 years old. Cohort 1 consisted of 91 (79.0\%) females and 24 males (21.0\%) who went through the course in the school year 2018, and cohort 2 consisted of 75 (79.8\%) females and 19 males (20.2\%) who participated in the course in the school year 2019. In the last decade, an extended 5-year teacher education program (4-years coursework and 1-year school internship) was widely implemented as a standard platform for new-coming teachers in Thailand at all levels of education. Later in 2019, there is a calling back for a new version of the traditional 4-year program to respond to the new Thailand Qualification Framework (TQF) and educational policy. Concerning the current transformation of the extended 5-year teacher education program in Thailand, the university is preparing to revise the teacher education program to be 4year program to meet the new framework, policy, and requirements, such as TPACK and STEM (Science, Technology, Engineering, Mathematics) education, and to improve the quality of teacher preparation. In this study, instruction is defined as coursework that encompasses a variety of technology-pedagogy interaction learning modules and learner-centered activities. The study was part of a course called classroom management and learning environment for science learning.

Both cohorts enrolled in the pedagogic course instructed by the first author. The course content was aligned with national undergraduate teacher education standards regarding Thailand qualification framework and emphasized on how to design, implement, and manage emerging technologies and science learning environments that promote meaningful learning in both elementary and secondary school science. One of the learning goals of the course was to apply theoretical knowledge of the learning sciences, such as digital game-based learning, inquiry-based learning, and information and communications technology in teaching and learning, as the method of teaching with technology to promote active inquiry learning in science, thus helping students to align learning theories with learning design practice for effective science learning. In 
cohort 1, they received an intervention of four-week mobile game-based inquiry learning taught by the first author. In planning for cohort 2, they received the same intervention with a reduced number of weeks in the course, because of the change of the teacher education program, and a difference in instructional design for the content. For both cohort 1 and 2, all were working toward licensure at the elementary or secondary levels. In terms of technological experience, all of them did have satisfactory basic information and communication technology skills but they had no any experience with using mobile game technology in science instruction before. In terms of learning experience, the participants had never taken an instructional design course but had some experience with group learning.

\section{A mobile game on blood circulatory system of human body}

An instructional game named "Red Blood Cell Simulator" has been created as an entertainment game with educational value, and it was used for the current study. In a previous study by Lokayut and Srisawasdi (2014), the computer game, in biological science topic of blood circulatory system of the human body, has been developed for assisting secondary school students' conceptual learning and their motivation to learn science. The game was built to align with two major learning indicators contained with the national curriculum standards: (1) to describe heart structure and its functions regarding blood and blood vessel and (2) to explain blood circulatory system. For this study, a new version in the context of the mobile game has been further designed and developed as a pedagogical tool for utilizing in pre-service teacher training. Before the game, an introduction of how to interact with the game was provided to guide players who may or may not be familiar to play a mobile game and assist them to realize what is the mission of the game and how to control a blood cell in the game, as shown in Fig. 4. Literature suggested that providing some instructional scaffolds or prompts before the game enhanced students' learning (e.g., Barzilai \& Blau, 2014, Tsai, Chai, Wong, Hong, \& Tan, 2013).

The Red Blood Cell Simulator mobile game has been designed as a serious educational game (SEG) - the content of the game is structured on a proposed curriculum with the intended learning outcomes (Annette, 2010). The game is in charge of executing the roleplaying game based on the biological science concepts. The role-playing game (RPG) is concerned with a storyline of the journey of a red blood cell, in which its purpose is to carry oxygen from the lungs to tissues throughout the body, as well as carrying carbon dioxide to the lungs so it can be exhaled. In this mobile game, the red blood cell goes through a complex journey through the body, going from a deoxygenated blood cell to an




oxygenated blood cell, and entering the heart twice. Figure 5 displays details of the mobile screen in the game.

During the learning process, the players play the role of the red blood cell to travel to the heart and organs via a blood vessel in circulation. To complete missions in the game, the students have to move the red blood cell to the right way and manage time. Besides, hints focusing on current position and mission guidelines are displayed during gameplay. After playing the game, students are shown feedback information to persuade them to rethink instances in which they failed the mission or to provide information about how to complete the mission. Following the storyline of the game, the players can collect the information needed to develop their scientific understanding of heart structure and its functions regarding blood and blood vessel and blood circulatory system.

In this study, the mobile-based "Red Blood Cell Simulator" game app is a gaming software application designed for science learning purposes through mobile devices. To create the pedagogical structure of the mobile game app, four principles from the science of learning have been emphasized, including (i) active involvement, (ii) learning engagement, (iii) meaningful experiences, and (iv) social interaction (Hirsh-Pasek, Zosh, Golinkoff, Gray, Robb, \& Kaufman, 2015). Besides, the game was carefully selected and recommended, as a cognitive tool, to the participating preservice science teachers as it had been shown to have a positive impact on science learning outcomes in previous empirical studies and employed game mechanics that mapped directly to learning standards, indicators, and objectives in Thailand national science curriculum (Lokayut \& Srisawasdi, 2014). In terms of the TPACK framework, these could refer to technological knowledge (TK) of playing the mobile games for preservice science teachers' professional learning. For promoting TCK, preservice science teachers should understand that the content of the blood circulatory system was transformed into simple knowledge representation to enhance the understanding of the complex biological processes of the human body system, and enjoyable scenarios to flow students' learning interactions and motivation. Concerning the pedagogy of science learning, the genre of the mobile RPG game can act as an implicit pedagogical approach to the particularly facilitate inquiry-

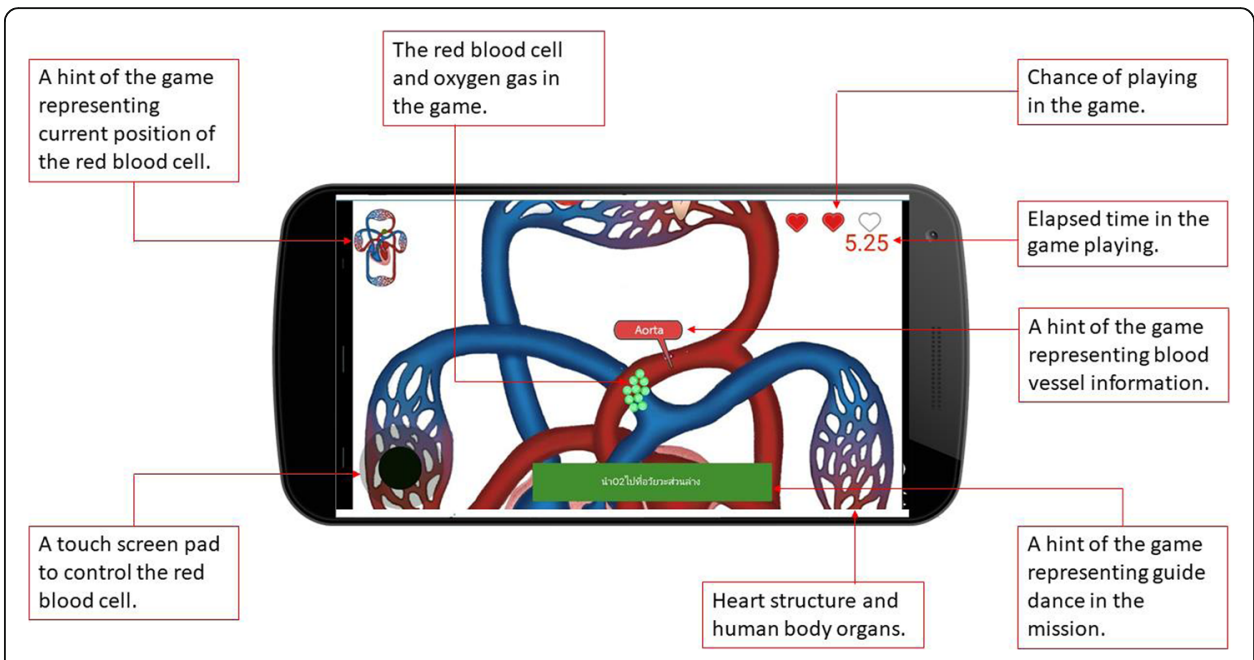

Fig. 5 An illustrative example of a storyline of red blood cell journey embedded in a gaming mission 
based learning in the game. This component targeted to professional learning of TPK for preservice science teachers. Finally, the TPCK in this study denotes knowing how the mobile game and the pedagogy of inquiry-based learning can be appropriately integrated with the content of the blood circulatory system in the human body to form sound lessons for the teaching of science. Those technology-infused components of the TPACK framework were used to facilitate the focus on content, pedagogy, and the game in this study.

\section{The setting of the training intervention}

The cohort 1 participants were introduced to a TPACK-based pedagogic module of mobile game-based inquiry learning in science (MGILS) for pre-service teachers. The MGILS module consisted of four 4-h weekly lecture and practical works, and divided into three phases: learning with technology (P1); enacting with technology through pedagogy (P2); transferring the technology-pedagogy interaction (P3) (Srisawasdi, Pondee, \& Bunterm, 2018), as shown in Table 1.

For cohort 2 in the next school year, participants interacted with a revised MGILS pedagogic training module for pre-service teachers. Research conducted by Lokayut and Srisawasdi (2014) and its digital game material has been employed as an instructional case study in the module. The case selected was not presented to increase factual information but rather to improve the participants' solid understanding of applying mobile games in inquiry-based learning in science content. This module covered 2 weeks and it was divided into three steps of instruction regarding case-based learning (CBL). CBL is a constructivist pedagogy which targets to real world situations by presenting richly detailed, contextualized, narrative accounts, and has the potential to prepare readiness for career challenges, promote critical thinking, contribute to cognitive growth, and affect value orientations for learners (Beck, 2007; Hemphill, $R$ Richards, Gaudreault, \& Templin, 2015; Levin, 1995). Further, Rovegno and Dolly (2006) pointed out that the CBL approach does not only presents concepts within a context to learners but actions are also illustrated to emphasize well-connected knowledge that learners can flexibly apply to learn about how to. In the context of implementing CBL to foster TPACK, Srisawasdi (2012) designed a pedagogic course with a CBL approach and then implement the course with 43 participants of preservice physics, chemistry, biology, mathematics, and computer teachers in a course of information and communication technology (ICT) in education. The result of this study showed a change in their teaching beliefs and the transformation of their TPACK

Table 1 Details of the MGILS module for cohort 1 pre-service science teacher

\begin{tabular}{|c|c|c|c|c|}
\hline Phase & Week & Topic & Learning strategy & Knowledge domain \\
\hline $\mathrm{P} 1$ & $1(4 \mathrm{~h})$ & $\begin{array}{l}\text { Introduction to digital and mobile } \\
\text { games in science learning }\end{array}$ & $\begin{array}{l}\text { Interactive lecture and } \\
\text { demonstration }\end{array}$ & TK \\
\hline \multirow[t]{2}{*}{ P2 } & $2(4 h)$ & Pedagogical application of MGILS & $\begin{array}{l}\text { Interactive lecture and } \\
\text { demonstration }\end{array}$ & TCK \\
\hline & $3(4$ h) & Hands-on practical work with MGILS & $\begin{array}{l}\text { Collaborative hands-on } \\
\text { practical work }\end{array}$ & TPK \\
\hline P3 & $4(4 h)$ & $\begin{array}{l}\text { Independent designing of MGILS } \\
\text { for school experience }\end{array}$ & $\begin{array}{l}\text { Collaborative hands-on } \\
\text { practical work }\end{array}$ & TPCK \\
\hline
\end{tabular}


competency in STEM teaching. Besides, Salton (2017) implemented online CBL to facilitate preservice teachers' TPACK and their self-confidence, and the result indicated that the online CBL method significantly improved their TCK and TK, but their TPAC K's confidence did not improve significantly. As such, CBL seems to be an effective pedagogic method to foster preservice teachers' TPACK. The CBL approach used in this study was adapted from William (2005), and the adapted approach consists of showing the case $(\mathrm{S})$, practice in the team $(\mathrm{P})$, and application of the case (A), shortly named SPA, as shown in Table 2.

For the $\mathrm{S}$ phase, the main aim was to introduce the selected case and to present information about instructional practice regarding mobile game-based inquiry learning in science. The pedagogy of inquiry-based learning in science emphasizing both instructional strategies, i.e., learning cycle-oriented and openness-oriented approach (Srisawasdi, 2016), and its application with the mobile game has been presented and analyzed to create a bridge between theory, research, and practice through interactive lecture and demonstration by the instructor (the first author). Moreover, the instructor also described and demonstrated how to play the game in the process of inquiry learning in science. In the P phase, the instructor organized a hands-on practical work experience as a mini-lesson on how to use the mobile game in a practical way of openinquiry science (Srisawasdi, 2012). Figure 6 shows learning activity in the S and P phases.

In the A phase of this module, all small groups of the participants have been assigned to collaboratively design mobile game-based inquiry learning experiences by their team. They were assigned to discuss in the team how to apply the Red Blood Cell Simulator mobile game for enhancing biological science learning of the blood circulatory system of the human body regarding the national science curriculum standards and indicators. After, they brainstormed and independently design a science lesson plan and presented their teaching ideas in class. Figure 7 illustrates the pre-service science teachers' collaborative designing the mobile game-based inquiry learning experience and presenting teaching ideas to the class groups.

\section{Data collection and analysis}

This study investigated the effects of using the training intervention as a tool for facilitating preservice science teachers' TPACK associating technology integration in

Table 2 Details of the MGILS module for cohort 2 pre-service science teacher

\begin{tabular}{lllll}
\hline Phase & Week & Topic & Learning strategy & $\begin{array}{l}\text { Knowledge } \\
\text { domain }\end{array}$ \\
\hline S & $1(2 \mathrm{~h})$ & $\begin{array}{l}\text { - Establishing and analyzing the case } \\
\text { - Demonstrating the research-based } \\
\text { MGILS }\end{array}$ & $\begin{array}{l}\text { Interactive lecture } \\
\text { and demonstration }\end{array}$ & $\begin{array}{l}\text { T-infused TPACK } \\
\text { - Formulating a study pathway }\end{array}$ \\
P & $1(2 \mathrm{~h})$ & $\begin{array}{l}\text { - Self-discovery of evidence through } \\
\text { practical work with MGILS } \\
\text { - Digesting essential knowledge of } \\
\text { TPACK of the case }\end{array}$ & $\begin{array}{l}\text { Collaborative } \\
\text { hands-on practical } \\
\text { work }\end{array}$ & T-infused TPACK \\
A & $\begin{array}{l}\text { Designing and proposing a MGILS } \\
\text { for school experience }\end{array}$ & $\begin{array}{l}\text { Collaborative } \\
\text { hands-on practical } \\
\text { work }\end{array}$ & T-infused TPACK \\
\hline
\end{tabular}

Note: T-infused TPACK refers to TK, TCK, TPK, and TPCK 

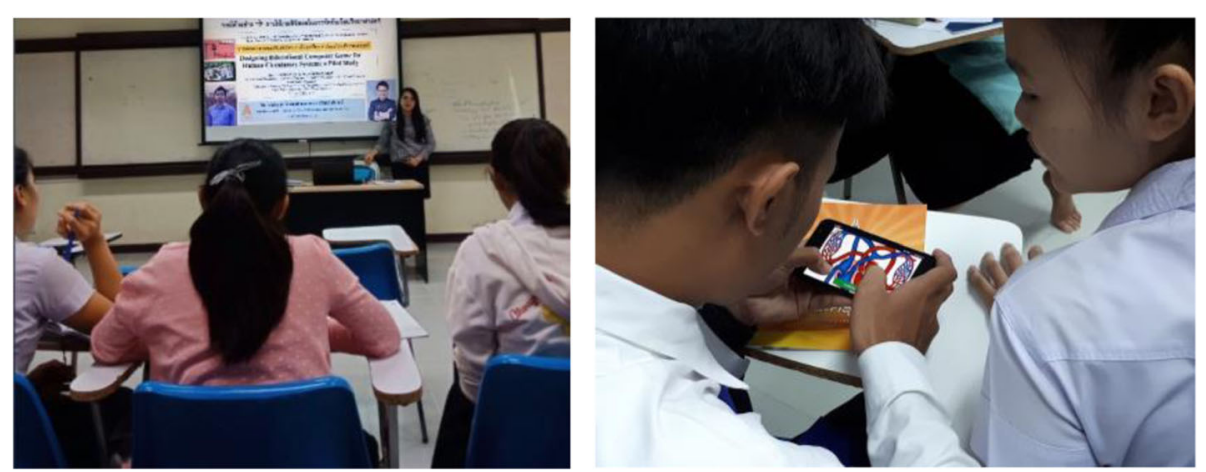

Fig. 6 An illustration of the showing the case (S) (left) and practice in team (P) (right) phases in preservice science teachers' class (Note: all photographs were permitted to be exhibited in this paper from people who was involved in this study)

two cohorts of preservice science teachers in Thailand. For cohort 1, the participants were asked to complete a seven-item open-ended question regarding TPACK in the context of MGILS for $40 \mathrm{~min}$ as pretest and posttest. In this study, the researchers focused on only four constructs related to technology regarding the TPACK framework (i.e., TK, TPK, TCK, and TPACK). The questionnaire and its scoring scheme were adapted from Srisawasdi, Pondee, \& Bunterm (2018), and the participants' responses to each test item were coded independently by two raters. For the coding, inter-rater reliability was computed using Cohen's kappa, and its reliability was 0.93 between the two raters. After calculating the inter-rater reliability, coding discrepancies among the raters were discussed and resolved through further personal discussion. Following this, if responses were unclear or problematic with the coding, the raters were discussed by the researchers (the second author) to reach a complete consensus agreement across the four targeted constructs. Thus, test construction can be considered successful in terms of objectivity and reliability. To analyze their TK, TPK, TCK, and TPACK for MGILS context, their responses were categorized in four levels, ranging from unclear, naïve, mixed, to informed, respectively, following Bartos and Lederman (2014)'s teaching conception analysis framework. In the analysis, their responses to individual questions were classified according to the examples and explanations presented in Lederman, Antink,
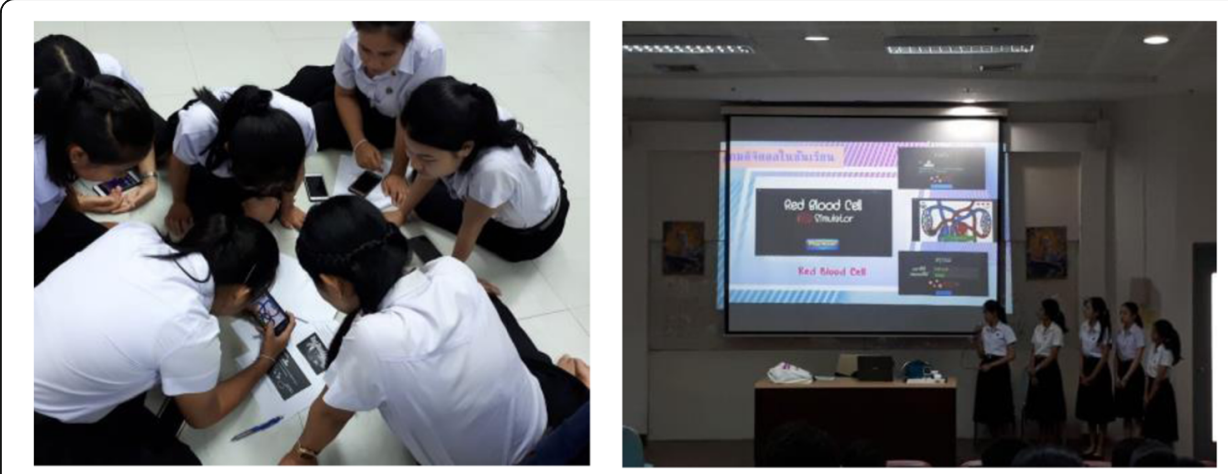

Fig. 7 An illustration of the application of the case (A) phase: collaborative designing a mobile game-based inquiry learning experience (left) and communicating teaching idea in class (right) (Note: all photographs were permitted to be exhibited in this paper from people who was involved in this study) 
and Bartos, (2014). For this study, the "Informed" level denotes views of a particular TPACK construct wholly match the target TPACK aspects, while the "Nä̈ve" level does not. "Mixed" level denotes reflecting partially consistent views of the target TPACK aspects. "Unclear" level denotes lacking in addressing the particular aspect (Lederman et al., 2014). Concerning the open-ended format of knowledge integration among CK, $\mathrm{PK}$, and TK, any essay-type questions is required additional effort by the researchers to discern the different levels of TPACK of the preservice science teachers. That is, this type of open-ended instrument was constructed with the four-tiered assessment scales to exploring general trends in the preservice science teachers' TPACK at the module. The format also best serves the overarching intent of the instrument, which is to create a profile of preservice science teachers' TPACK.

To examine a significant effect of the revised MGILS module in cohort 2, the researchers assessed TPACK improvement by comparing its scores before and after receiving the intervention. A ten-item close-ended questionnaire measuring TPACK in mobile game-based inquiry learning in science was developed by the researchers regarding the previous seven-items open-ended question items. The answers in the questionnaire are based on common pre-service science teachers' replies to the openended questions which common errors were used to create distracters. As abovementioned, this study focused on only TK, TPK, TCK, and TPACK, the responses obtained from six closed-ended question items were the unit of TPACK score analysis and the total score was six points. The item discrimination index of the multiple-choice test was > 0.03 for all items (average 0.54) and Kuder-Richardson Formula 20 (KR-20) reliability coefficient was 0.83 . To confirm the normal distribution of our data, the researchers performed the Shapiro-Wilk test and the normality of distribution of data was denied for both pretest $(W=0.926 ; p<0.000)$ and posttest $(W=0.925 ; p<0.000)$. Because the preservice science teachers' scores on the scales of TPACK did not fit the assumptions of the normal distribution, the researchers implemented Wilcoxon signedrank test to examine whether the preservice science teachers' TPACK changed after being involved in the intervention. In further statistical analysis, the quantitative data of TPACK scores obtained from pretest and posttest were analyzed with the means, standard deviations, and Wilcoxon signed-rank test, to compare a significant difference. All of the statistical tests were analyzed using the IBM SPSS program, version 26.00, with a significance level of .05 . Moreover, the effect size $(r)$ for the Wilcoxon signedrank test was also calculated by using the formula: $Z / \sqrt{ } N$ ( $N$ is the number of the pairs).

\section{Results}

In our study, we recognized the importance of a pipeline of evidence that begins with a qualitative study, as primary evidence for initial investigating the effects of proposed instructional intervention and also assisting us to maximize the instructional intervention to targeted study participants and then ends with a quantitative study. Moreover, we conducted firstly with the qualitative study which could assist us to design the better and possible research process in the later quantitative study. As we stated, this study aimed to discover whether the benefits of well-design teaching practice focusing on the integrative use of the mobile game in school science class for promoting preservice science teachers' TPACK can contribute to the accumulation of empirical evidence and development of theoretical models for the preparation of today's teacher education. We 
have conducted two distinct studies in which we have used the TPACK framework as a preservice teacher preparation platform to enhance preservice science teachers' emerging pedagogy of mobile game integration.

To promote preservice science teachers' emerging pedagogy of mobile game technology integration in this study, a pedagogic module of mobile game-based inquiry learning in science (MGILS) has been designed which represents our attempt to maximize their TPACK in term of four constructs: (i) technological knowledge (TK), (ii) technological content knowledge (TCK), (iii) technological pedagogical knowledge (TPK), and (iv) technological pedagogical content knowledge (TPCK). In this teaching improvement study, two cohorts had been implemented with the two different pedagogical settings of the MGILS: (i) usual separated TPACK and (ii) integrated case-based TPACK support module. In the first study, cohort 1 received the MGILS in the version of separating TK, TCK, TPK, and TPCK, and the first study had been conducted with a qualitative study to provide phenomenological evidence of the intervention on how it works in fostering preservice science teachers' TK, TCK, TPK, and TPCK. In the second study, cohort 2 received the integrated and synthetic version of MGILS integrating all the four TPACK constructs into the teaching case, and we explored the effect of the revised intervention with a quantitative study to indicate a significant impact of revised MGILS on preservice science teachers' TPACK of mobile game integration. Besides, the results of cohort 1 implementation represent our first attempt to answer the first research question, and cohort 2 represents our pursuit to improvise the MGILS module with some critical change in teacher education program, and argue to an impact of the specific type of TPACK implementation. We believed this approach would be helpful by locating our study in a more thorough design and hopefully getting a more robust finding in developing preservice science teachers' TPACK of mobile game integration.

\section{What are preservice science teachers' TPACK of inquiry-based conceptual learning in science by mobile game before and after an implementation of usual TPACK-based pedagogic module of MGILS?}

Regarding the first research question, this study utilized quantitative content analysis to reveal the preservice science teachers' TPACK both before and after receiving the usual MGILS module as a training intervention. According to explore the effect of usual MGILS module on cohort 1 pre-service science teachers' TPACK, focusing TK, TPK, TCK, and TPACK, the results are shown in Table 3.

Individual profiles were developed based on a holistic analysis of TPACK responses. Results indicated that most of preservice science teachers' TK (a) were mixed level in both prior and finish to the intervention, and (b) increase their understanding from unclear and naïve to mixed level. For TPK and TCK, the results indicated that their knowledge (a) was distributed from unclear to informed before the intervention, and (b) both increase and decrease their knowledge to mixed level. Finally, the results also indicated that most of their TPACK (a) were unclear level in both prior and finish to instruction, and (b) increase their understanding from unclear and naïve to mixed and informed levels. More details regarding the preservice science teachers' TK, TPK, TCK, and TPACK levels are illustrated in Table 4. 
Table 3 Percentage of the pre-service science teachers' TK, TPK, TCK, and TPACK categorized as holding unclear, naïve, mixed, and informed views of TPACK

\begin{tabular}{|c|c|c|c|c|c|c|c|c|}
\hline \multirow{2}{*}{$\begin{array}{l}N=115 \\
\% \text { of pre-service science teachers }\end{array}$} & \multicolumn{2}{|c|}{ Unclear } & \multicolumn{2}{|l|}{ Naïve } & \multicolumn{2}{|c|}{ Mixed } & \multicolumn{2}{|c|}{ Informed } \\
\hline & Pre & Post & Pre & Post & Pre & Post & Pre & Post \\
\hline $\begin{array}{l}\text { Technological knowledge } \\
\text { (TK) }\end{array}$ & 28.70 & 18.26 & 27.83 & 0.00 & 42.61 & 80.87 & 0.87 & 0.87 \\
\hline $\begin{array}{l}\text { Technological pedagogical knowledge } \\
\text { (TPK) }\end{array}$ & 31.30 & 29.57 & 46.96 & 43.48 & 20.00 & 26.96 & 1.74 & 0.00 \\
\hline $\begin{array}{l}\text { Technological content knowledge } \\
\text { (TCK) }\end{array}$ & 37.39 & 55.65 & 37.39 & 0.00 & 24.35 & 44.35 & 0.87 & 0.00 \\
\hline $\begin{array}{l}\text { Technological pedagogical and } \\
\text { content knowledge } \\
\text { (TPACK) }\end{array}$ & 46.96 & 38.26 & 26.09 & 22.61 & 26.96 & 38.26 & 0.00 & 0.87 \\
\hline
\end{tabular}

Table 4 provides example responses to each of the open-ended items regarding TK, TPK, TCK, and TPACK. These are verbatim quotes selected from the responses of preservice science teachers who completed the open-ended items at pre- and post-MGILS module. The naïve view respondent examples are taken from pretests and the more informed examples are taken from the posttests. These views are presented along a continuum from naïve to more informed TK, ТРК, ТCK,

Table 4 Exemplary responses in all level across four categories (i.e., TK, TPK, TCK, TPACK)

\begin{tabular}{|c|c|c|c|}
\hline $\begin{array}{l}\text { Knowledge } \\
\text { category }\end{array}$ & Unclear view & Naïve view & Mixed view \\
\hline $\begin{array}{l}\text { Technological } \\
\text { knowledge } \\
\text { (TK) }\end{array}$ & $\begin{array}{l}\text { "Digital technology." } \\
\text { (PST022) }\end{array}$ & $\begin{array}{l}\text { "Digital game } \\
\text { provides enjoyment." } \\
\text { (PST043) }\end{array}$ & $\begin{array}{l}\text { "Digital game offers } \\
\text { challenge to pass } \\
\text { missions." (PST111) }\end{array}$ \\
\hline
\end{tabular}

Informed view

"Digital game allows students to accomplish missions and interact with its challenge to receive points and rewards." (PST111)

$\begin{array}{ll}\text { Technological } & \text { "This technology } \\ \text { pedagogical } & \text { offers students to } \\ \text { knowledge } & \text { have fun. Pedagogy } \\ \text { (TPK) } & \text { can support to } \\ & \text { simplify } \\ & \text { understanding." } \\ & \text { (PST009) }\end{array}$

Technological "Digital technology content proposes challenge knowledge accomplishing (TCK) missions and fun." (PST005)

Technological pedagogical and content knowledge (TPACK)

"All components are important for teaching. Students are also an effective factor." (PST033)
"Digital game is used to support pedagogy for science content learning. So, students were getting more interest in the learning." (PST095)

"Digital game is fun and we can play much time. It can be applied in biological science content."(PST103)
"It (digital game) can help students to gain more understanding." (PST007)
"Digital game can support teacher to assist students to learn science by no explaining science content, but the teacher can facilitate students how to play the game." (PST037)

"Digital game transformed boring science content to be more interesting and challenge with its mission, rewards, and the way how to win the game."(PST073)

"Teacher assigned task that provides students to interact with the digital game to learn about the science content." (PST019)
"Student can inquire science information by playing the game and also learn how to investigate scientific phenomena with inquiry in the game." (PST 083)

"Digital game can convert the content difficult to be easier to understanding, enjoyment, and doing practical work with playing" (PST016)

"Content, pedagogy, and technology are associated with each other for enhancing students learning in science. Playing and learning with fun is in the inquiry learning process, where content has been changed in-game style." (PST023) 
and TPACK. Despite receiving overall positive results as abovementioned, the researchers also found some apathy toward the implementation of usual MGILS. The results indicate that the number of unclear levels on TCK was increased and the informed level of TPK and TCK were disappeared after receiving the usual teaching intervention, as seen in Table 3.

In summary, the results of this preliminary study provided evidence that preservice science teachers' TK, TPK, TCK, and TPACK have been fostered during their interaction with the usual MGILS pedagogic module, and this teaching intervention still had various effects on preservice science teachers' TPACK.

Is there a significant difference between preservice science teachers' TPACK before and after implementation of the revised, case-based approach, MGILS?

The second research question focused on examining whether the pedagogic module of MGILS improved cohort 2 preservice science teachers' TPACK associated technology scores, descriptive statistics were calculated, and nonparametric tests were conducted. The descriptive statistics of the preservice science teachers' pre- and post-test TPACK scores are presented in Table 5. The result shows that there was a statistically significant difference between the pretest $(M=1.93, \mathrm{SD}=1.34)$ and post-test $(M=3.78, \mathrm{SD}=1.20)$ scores, the total score is six points.

As shown in Table 5, Wilcoxon's signed-rank test was used to test the significance of the difference between pretest and post-test TPACK mean scores. Table 5 shows that the preservice science teachers' TPACK scores after the intervention $\left(Z_{(94)}=-7.571, p<.001\right)$ were significantly higher than the preservice science teachers' TPACK scores before the intervention. Table 5 is also shown that the differences between the preservice science teachers' TPACK in the pre- and post-tests reached a large effect size $(r=-0.78)$. Overall, the pre-service science teachers' TK, TCK, TPK, and TPACK significantly improved after participating with the case-based MGILS module $(p<0.001)$ as measured by the increase in TPACK scoring.

\section{Discussions and conclusions}

The present study facilitated a series of course transformations as a means of developing preservice science teachers' teaching comprehension with the digital or mobile games and also investigated the effects of the technology-oriented

Table 5 Wilcoxon signed-rank test results of the difference between the pre- and post-test TPACK scores

\begin{tabular}{lllllll}
\hline Pre- and post-test measurements & $\boldsymbol{n}$ & Mean rank & Rank sum & $\boldsymbol{Z}$ & $\boldsymbol{p}$ & $\boldsymbol{r}$ \\
\hline Negative rank & 4 & 14.00 & 56.00 & -7.571 & $0.000^{*}$ & -0.78 \\
Positive rank & 76 & 41.89 & 3184.00 & & & \\
Tie & 14 & & & & & \\
Total & 94 & & & & & \\
\hline
\end{tabular}

${ }^{*} p \leq .001$, indicates a significant change from pretest to post-test 
pedagogic module of Mobile Game-based Inquiry Learning in Science (MGILS) on preservice science teachers' TPACK. The results indicate that a significant difference between their TPACK scores at the pre- and post-tests, and this revealed that the revised, case-based approach, MGILS improved their technology-oriented TPACK, in term of TK, TPK, TCK, and TPACK for the pedagogical integration of mobile game into school science class. This result is consistent with Jimoyiannis (2010), Jang and Chen (2010), Srisawasdi (2012), Srisawasdi (2014), Srisawasdi and Panjaburee (2014), and Srisawasdi, Bunterm, and Pondee (2018) that implementation of well-designed coursework could foster preservice or in-service science teachers' essential knowledge of TPACK. In the present study, the finding suggests that when integrating a case-based approach to delivering the content of how to teach science through the inquiry learning process by using mobile game into the school science context tended to raise the preservice science teachers' competencies in TK, TPK, TCK, and TPACK. It was likely that inducing them into the establishing and analyzing of research-based case study first, in the showing the case (S) phase, allowed the preservice science teacher to perceive relative advantage of mobile game technology in school science improvement as well as to get an idea of how mobile game worked to enhance inquiry-based inquiry science learning and to transform knowledge representations of science content. This may help them articulate their tacit knowledge about instruction (e.g., TK, TPK, TCK) and then foster their TPACK (Scott et al., 2008; Sahin, 2012). Moreover, preservice science teachers can realize theoretical aspects of instructional models for using technology in education, and also learn about the effects of using technology and specific learning model or method for promoting better learning through the presented case (Han, Eom, \& Shin, 2013). In the collaborative hands-on practical work to discover how to pedagogically integrate the mobile game into a science content-specific domain, in the practice in team (P) phase, this process allows richer contexts to preservice science teachers to build integrative knowledge about how to embed technology into particular learning model and when to apply the models or theories in different instructional situations (Kurz \& Batarelo, 2010; Sahin, 2012; Sutton, 2011; Zhang et al., 2011). Besides, the principle of setting an anchor by case study and of segmenting the case (e.g., breaking a whole presentation into coherent parts that can be digested sequentially) is an effective pedagogical support to improve learning and memory (McLarty et al., 1990; Mayer, 2009). As such, digesting essential knowledge of TPACK of the case after the hands-on experience could be a supportive factor to indicate focal points that provide a link for preservice science teachers' perception and comprehension. Furthermore, preservice science teachers worked in collaborative teams, in the application of the case (A) phase, to design a school science learning experience. The team was anchored by the case-based MGILS and then ultimately creates an artifact of mobile game-integrated science lesson regarding the case. Alayyar (2011), Koehler and Mishra (2005), and Shin, et al. (2009) stated that the collaboration and design of artifacts to solve real-world instructional problems enhanced preservice teachers develop a better understanding of how to use technology in instruction to enhance learning and 
potentially increasing their abilities to integrate technology fitting pedagogy in the classroom and curriculum content. These features link to the aforementioned finding that preservice science teachers' TK, TPK, TCK, and TPACK have been improved significantly after receiving the case-based MGILS (see Table 5). As such, it is reasonable to say that the case-based MGILS seems to benefit preservice science teachers' TPACK development more as it allows them to accumulate professional learning experiences with particular research-based case studies following S-P-A phases. Thus, this implies the possibility of improving preservice science teachers' TPACK of mobile game-based inquiry learning in science and it could be an effective way to develop their essential knowledge of mobile technology-enhanced learning in science to address the twenty-first-century education requirement.

The results of this study have practical implications for teacher educators since the findings increase our understanding of how to design effective technology-integrated pedagogical learning modules that promote the improvement of TK, TPK, TCK, and TPACK in the context of mobile game-based inquiry learning in science for preservice teachers. Also, teacher educators can gain a more insightful view on how the adapted TPACK emphasizing mobile game-based inquiry learning in science can be implemented pedagogically in preservice science teachers' professional preparation in the teacher education programs.

However, more teacher education research needs to be conducted to maximize the improvement of preservice science teachers' TPACK by redesigning the pedagogic module of mobile game-based inquiry learning in science, and this study still has several limitations. Although the findings were framed in the literature on technology-integrated pedagogical approaches in teacher education, this study was, firstly, based on the implementation and evaluation of only one pedagogical module of mobile game-based inquiry learning in science of one science teacher education program. Therefore, the researchers should make it clear that the findings of this study should not be generalized to the pedagogical module of mobile game-based inquiry learning in science in different teacher education contexts. Secondly, another limitation of this study was the sample population utilized. The research study only recruited preservice science teachers from a specific science teacher education program at a small university that only offers one major of science education program that is general science. Other majors of science teacher education programs, such as physics education, chemistry education, biology education, should also be studied. Thirdly, both cohorts of preservice science teachers were investigated their TPACK in different measurement methods. Both quantitative and qualitative methods should be emphasized in a balance and utilized to examine the effects of the usual and revised pedagogic module of mobile game-based inquiry learning in science on preservice science teachers' TPACK, and gainfully understand the transformation of knowledge related TPACK. Fourthly, to gain more deepen insight on how to completely foster preservice science teachers' TPACK, all seven TPACK constructs should be investigated to indicate an impact of the teaching intervention. 


\section{Appendix}

An example of open-ended question item in measuring preservice science teachers' TPACK

Situation no.1:

Teacher A taught a chemical concept of ionization energy to particularly promote students' conceptual understanding of the trends in ionization energy across the periodic table. In the chemistry class, teacher created an investigative learning experience with the support of digital technology, which can create personal challenge through missions and/or tasks in multi-levels. In addition, the teacher provided an essential question to all students and then students could interact personally in groups with the technology by playing and receiving rewards regarding their missions/or tasks accomplishment. In the end, students had been assigned to present their group answers to the prescriptive question.

\begin{tabular}{|c|c|c|}
\hline Questions related to TPACK & Purpose of the question. & The answer \\
\hline $\begin{array}{l}\text { 1) Please describe the scientific } \\
\text { concept of ionization energy (SC) }\end{array}$ & $\begin{array}{l}\text { This question allows you to express } \\
\text { your scientific conceptual } \\
\text { understanding of a specific content } \\
\text { area. }\end{array}$ & $\begin{array}{l}\text { The general trend is for ionization } \\
\text { energy to increase moving from } \\
\text { left to right across an element } \\
\text { period. Moving left to right across a } \\
\text { period, the atomic radius decreases, } \\
\text { so electrons are more attracted to } \\
\text { the (closer) nucleus. In addition, the } \\
\text { general trend is for ionization } \\
\text { energy to decrease moving from } \\
\text { top to bottom down a periodic } \\
\text { table group. Moving down a group, } \\
\text { a valence shell is added. The } \\
\text { outermost electrons are further } \\
\text { from the positive-charged nucleus, } \\
\text { so they are easier to remove. }\end{array}$ \\
\hline
\end{tabular}

2) According to the abovementioned situation, what is the teaching strategy used (TS) by the teacher, please describe?
This question allows you to describe the pedagogy or learning approach conducted by the teacher based on your interpretation.
3) According to the

abovementioned situation, what is the technological tool used (TT) by the teacher, please describe?

4) In this situation, is the TS used influences to facilitate the SC learning, please describe?
This question allows you to describe a specific kind of digital learning technology implemented by the teacher based on your interpretation.

This question allows you to explain how the selected pedagogy or learning approach could positively facilitate the learning of specific scientific content, based on your interpretation.
Inquiry-based learning has been characterized as an approach in which teachers will provide challenge problem/essential question and set up the background and context, while students must determine the procedure/design, perform the investigation based on the specified design, and then make the scientific communication and draw their answers as conclusions.

[Here is your answer.]

To promote an effective investigative learning experience, an inquiry-based learning approach is a recommended teaching strategy to address the learning of science by its nature. To enhance students' conceptual learning of ionization energy trends, the inquiry learning process can facilitate their direct experience of exploration to collect data and/or evidence, and then draw a particular conclusion regarding the posed question in learning activities. 


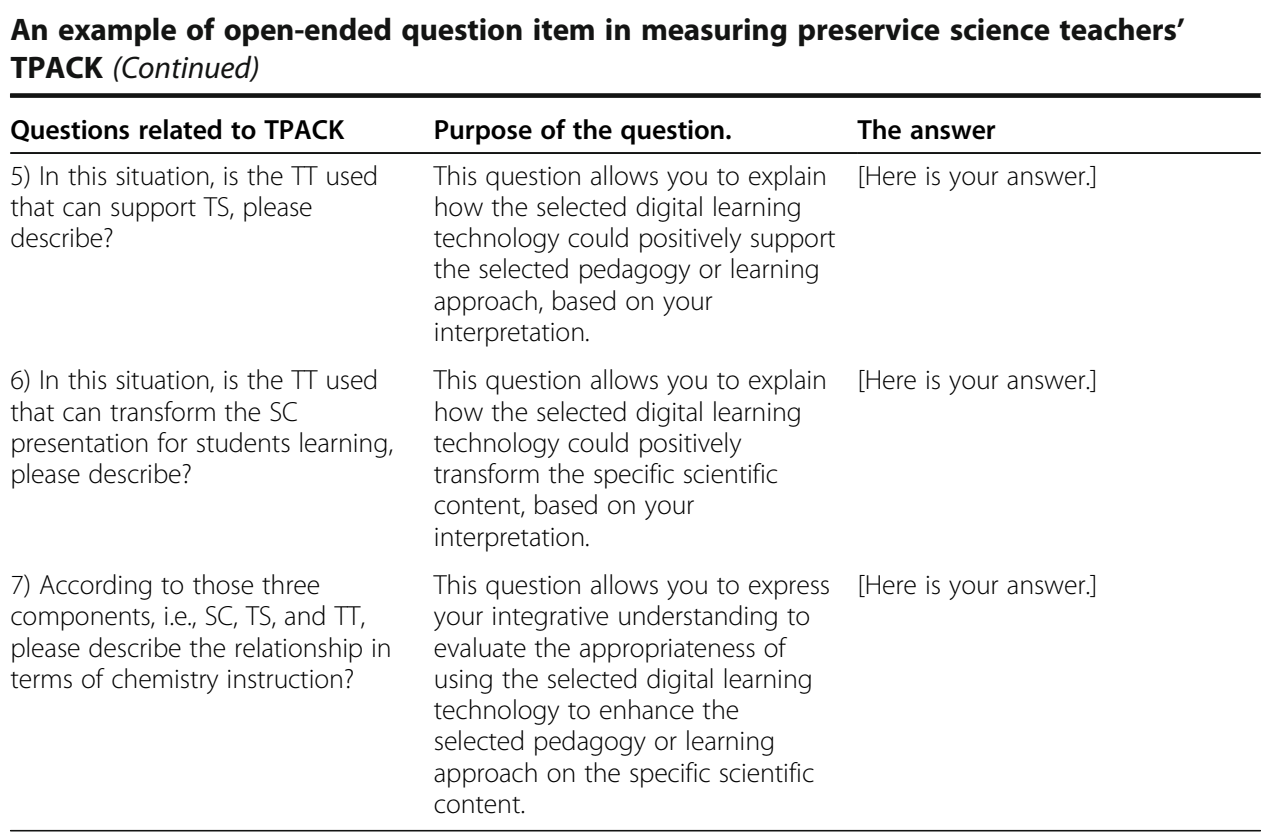

(Note: This is a translation of original version in Thai language)

Examples of a close-ended question item in measuring preservice science teachers' TPACK

1. Which technological tool is able to use to characterize content of learning as narrative story or scenario, and student can interact with the tool through playing in missions, having challenge and fun with different unique situations, receiving rewards and upgrade to higher level by mission accomplishment? (Note: TK measurement)
A. Simulation
B. Animation
C. Augmented Reality (AR)
D. Digital Game

2. According to the content-specific domain of blood circulatory system, which technological tool can change the representation of the content into the most challenging mission and maximizing learning enjoyment during playing with mission?

(Note: TCK measurement)
A. Animation
B. Digital Game
C. Simulation
D. Augmented Reality (AR)

(Note: This is a translation of original version in Thai language)

3. According to the use of mobile game to facilitate inquiry-based learning, which technological tool can change the representation of the content into the most challenging mission and maximizing learning enjoyment during playing with mission? (Note: TPK measurement)

A. It can support students' inquiry to measure scientific signals and then automatically display the obtained raw data from the measurement. 
B. Students can immediately check the correction of their investigation, and then personally receive feedback from their interaction.

C. It creates particular challenge to students to investigate target learning phenomena by receiving rewards and scores from playing.

D. Students can inquire into the relationship among variables and visualize the learning phenomena in invisible level.

\title{
(Note: This is a translation of original version in Thai language)
}

\author{
Abbreviations \\ MGILS: Mobile game-based inquiry learning in science; PST: Preservice science teacher; CBL: Case-based learning; \\ SEG: Serious educational game; DGBL: Digital game-based learning; MGBL: Mobile game-based learning; RPG: Role- \\ playing game; REG: Repertory grid-based educational game; TPACK-G: Technological pedagogical and content \\ knowledge-games; GPK: Game pedagogical knowledge; GPCK: Game Pedagogical Content Knowledge; \\ TPACK: Technological pedagogical and content knowledge; TPK: Technological pedagogical knowledge; \\ TCK: Technological content knowledge; PCK: Pedagogical content knowledge; TK: Technological knowledge; \\ PK: Pedagogical knowledge; CK: Content knowledge; SPSS: Statistical Package for the Social Sciences
}

\section{Acknowledgements}

The authors would like to express their gratitude to the Faculty of Education at Roi Et Rajabhat University for providing administrative support. Also, the authors thank all preservice science teachers at the Faculty of Education who participated in this work. In addition, the authors would like to thank Mr. Jatuput Lokayuth, biology teacher at Udonpittayanukoon School, Udon Thani, Thailand, for his assistance in designing and preparing the digital game of blood circulatory system.

\section{Authors' contributions}

Phattaraporn Pondee reviewed the previous studies, developed and implemented the experimental treatments, performed the data collection and analyzed, concluded the study, and wrote a draft of the paper. Niwat Srisawasdi conceptualized the study, assisted in designing the study and interpretation of data, supervised the work progress, discussed the results, and reviewed and edited the manuscript. Patcharin Panjaburee assisted in validating the study and edited the manuscript. All authors read and approved the final manuscript.

\section{Authors' information}

Phattaraporn Pondee is currently a lecturer at general science education program, Faculty of Education, Roi-et Rajabhat University, Thailand. She earned her master degree in science education and she is currently also a Ph.D. candidate Science Education program at Faculty of Education, Khon Kaen University, Thailand. Her research interests include technology-based inquiry learning in biological science and technological pedagogical content knowledge in physical and biological science.

Patcharin Panjaburee is currently an associate professor of Institute for Innovative Learning, Mahidol University, Thailand. She is interested in computer-assisted testing, adaptive learning, expert systems, and digital material supported learning, inquiry-based mobile learning, and web-based inquiry learning environment.

Niwat Srisawasdi is currently an assistant professor at Division of Science, Mathematics, and Technology Education, Faculty of Education, Khon Kaen University, Thailand. He is also a deputy dean of Research and Creative Educational Innovation at the faculty. His research interests include technology-enhanced learning in science, digital learning, nanoscience and nanotechnology education, and technological pedagogical and content knowledge in STEM fields.

\section{Funding}

This work was financially supported by the Thailand Research Fund (TRF), the Commission on Higher Education (CHED) and Khon Kaen University (KKU) (Grant no. RSA6280062). Any opinions, findings, and conclusions or recommendations expressed in this material are of the authors and do not necessarily reflect the view of the TRF, CHED, and KKU.

\section{Availability of data and materials}

The datasets generated and/or analyzed during the current study are not publicly available due to the maintaining privacy and confidential of the data, and reasonable use for scientific research purposes only, but are available from the corresponding author on reasonable request.

\section{Declarations}

Competing interests

The authors declare that they have no competing interests.

\section{Author details}

${ }^{1}$ Faculty of Education, Khon Kaen University, Khon Kaen, Thailand. ${ }^{2}$ Institute for Innovative Learning, Mahidol University, Salaya, Thailand. 
Received: 7 September 2020 Accepted: 10 March 2021

Published online: 25 June 2021

\section{References}

Alayyar, G. (2011). Developing pre-service teacher competencies for ICT integration through design teams (Doctoral dissertation). Enschede, the Netherlands: University of Twente. Retrieved from http://doc.utwente.nl/77918/

Annetta, L. A. (2010). The "I's" have it: a framework for educational game design. Review of General Psychology, 14(2), $105-112$. https://doi.org/10.1037/a0018985.

Antunes, M., Pacheco, M. A. R., \& Giolanela, M. (2012). Design and implementation of an educational game for teaching chemistry in higher education. Journal of Chemical Education, 89(4), 517-521.

Bartos, S. A., \& Lederman, N. G. (2014). Teachers' knowledge structures for nature of science and scientific inquiry: conceptions and classroom practice. Journal of Research in Science Teaching, 51(9), 1150-1184. https://doi.org/10.1002/ tea. 21168 .

Barzilai, S., \& Blau, I. (2014). Scaffolding game-based learning: impact on learning achievements, perceived learning, and game experiences. Computers \& Education, 70, 65-79. https://doi.org/10.1016/j.compedu.2013.08.003.

Baker, W. M., Lusk, E. J., \& Neuhauser, K. L. (2012). On the use of smartphones and other devices in the classroom: Evidence from a survey of faculty and students. Journal of Education for Business, 87(2), 275-289.

Beck, J. (2007). An exploration of the relationship between case study methodology and learning style preference. Journal of Science Teacher Education, 18(3), 423-430. https://doi.org/10.1007/s10972-007-9056-5.

Becker, K. (2007). Digital game-based learning once removed: teaching teachers. British Journal of Educational Technology, 38(3), 478-488. https://doi.org/10.1111/j.1467-8535.2007.00711.x.

Cetin-Dindar, A., Boz, Y., Sonmez, D. Y., \& Celep, N. D. (2018). Development of pre-service chemistry teachers' technological pedagogical content knowledge. Chemistry Education Research and Practice, 19(1), 167-183.

Chang, C.-Y. \& Hwang, G.-J. (2019). Trends in digital game-based learning in the mobile era: A systematic review of journal publications from 2007 to 2016. International Journal of Mobile Learning and Organisation, 13(1), 68-90.

Chen, C., Liu, H., \& Huang, H. (2019). Effects of a mobile game-based English vocabulary learning app on learners' perceptions and learning performance: A case study of Taiwanese EFL learners. ReCALL, 31(2), 170-188.

Chittleborough, G. (2018). Pre-service teachers' experiences with integrating technology into their learning and teaching. Journal of Science Teacher Education, 25(4), 373-393.

Daungcharone, K., Panjaburee, P., \& Thongkoo, K. (2019). A mobile game-based C programming language learning: Results of university students' achievement and motivations. International Journal of Mobile Learning and Organisation, 13(2), 171192.

Foster, A., \& Shah, M. (2020). Principles for advancing game-based learning in teacher education. Journal of Digital Learning in Teacher Education, 36(2), 84-95. https://doi.org/10.1080/21532974.2019.1695553.

Gamlo, N. (2019). The impact of mobile game-based language learning apps on EFL learners' motivation. English Language Teaching, 12(4), 49-56

Hakak, S., Noor, N. F. M., Ayub, M. N., Affal, H., Hussin, N., \& Imran, M. (2019). Cloud-assisted gamification for education and learning - Recent advances and challenges. Computers \& Electrical Engineering, 74, 22-34.

Han, I., Eom, M., \& Shin, W. S. (2013). Multimedia case-based learning to enhance pre-service teachers' knowledge integration for teaching with technologies. Teaching and Teacher Education, 34, 122-129.

Hemphill, M. A., R Richards, K. A., Gaudreault, K. L., \& Templin, T. J. (2015). Pre-service teacher perspectives of case-based learning in physical education teacher education. European Physical Education Review, 21(4), 432-450. https://doi.org/1 $0.1177 / 1356336 \times 15579402$.

Hirsh-Pasek, K., Zosh, J. M., Golinkoff, R. M., Gray, J. H., Robb, M. B., \& Kaufman, J. (2015). Putting education in "educational" apps: lessons form the science of learning. Psychological Science in the Public Interest, 16(1), 3-34. https://doi.org/10.11 $77 / 1529100615569721$.

Hsu, C. Y., Liang, J. C., Chai, C. S., \& Tsai, C. C. (2013). Exploring preschool teachers' technological pedagogical content knowledge of educational games. Journal of Educational Computing Research, 49(4), 461-479. https://doi.org/10.21 90/EC.49.4.C.

Hsu, C. Y., Liang, J. C., Chuang, T. Y., Chai, C. S., \& Tsai, C. C. (2020). Probing in-service elementary school teachers' perceptions of TPACK for games, attitudes towards games, and actual teaching usage: a study of their structural models and teaching experiences. Educational Studies, 1-17. https://doi.org/10.1080/03055698.2020.1729099.

Hsu, C. Y., Liang, J. C., \& Su, Y. C. (2015). The role of the TPACK in game-based teaching: does instructional sequence matter? The Asia-Pacific Education Researcher, 24(3), 463-470. https://doi.org/10.1007/s40299-014-0221-2.

Hsu, C. Y., \& Tsai, C. C. (2013). Examining the effects of combining self-explanation principles with an educational game on learning science concepts. Interactive Learning Environments, 21(2), 104-115.

Huizenga, J., Admiraal, W., Dam, G. T., \& Voogt, J. (2019). Mobile game-based in secondary education: Students' immersion, game activities, team performance and learning outcomes. Computer in Human Behavior, 99, 137-143.

Hussein, M. H., Ow, S. H., Cheong, L. S., \& Thong, M.. (2019). A digital game-based learning method to improve students' critical thinking skills in elementary science. IEEE Access, 7, 96309-96318.

Hwang, G.-J., Lai, C.-L., \& Wang, S.-Y. (2015). Seamless flipped learning: A mobile technology-enhanced flipped classroom with effective learning strategies. Journal of Computers in Education, 2, 449-473.

Hwang, G.-J., Sung, H.-Y., Hung, C.-M., Huang, I., \& Tsai, C.-C. (2012). Development of a personalized educational computer game based on students' learning styles. Educational Technology Research and Development, 60(4), 623-638.

Jang, S. J., \& Chen, K.-C. (2010). From PCK to TPACK: Developing a transformative model for pre-service science teachers. Journal of Science Education and Technology, 19(6), 553-564. https://doi.org/10.1007/s10956-010-9222-y.

Janssen, N., Knoef, M., \& Lazonder, A. W. (2019). Technological and pedagogical support for pre-service teachers' lesson planning. Technology, Pedagogy and Education, 28(1), 115-128. https://doi.org/10.1080/1475939X.2019.1569554.

Janssen, N., \& Lazonder, A. W. (2016). Supporting pre-service teachers in designing technology-infused lesson plan. Journal of Computer Assisted Learning, 32(5), 456-467. 
Jimoyiannis, A. (2010). Designing and implementing an integrated technological pedagogical science knowledge framework for science teachers professional development. Computers \& Education, 55(3), 1259-1269. https://doi.org/10.1016/j. compedu.2010.05.022

Kafai, Y. B., \& Burke, Q. (2015). Constructionist gaming: understanding the benefits of making games for learning. Educational Psychologist, 50(4), 313-334. https://doi.org/10.1080/00461520.2015.1124022.

Koehler, M. J., \& Mishra, P. (2005). What happens when teachers design educational technology? The development of technological pedagogical content knowledge. Journal of Educational Computing Research, 32(2), 131-152. https://doi. org/10.2190/0EW7-01WB-BKHL-QDYV.

Koehler, M. J., \& Mishra, P. (2008). Introducing TPACK. In AACTE Committee on Innovation \& Technology (Ed.), Handbook of technological pedagogical content knowledge for educators, (pp. 3-29). New York, NY: Routledge.

Komalawardhana, N., \& Panjaburee, P. (2018). Proposal of personalised mobile game from inquiry-based learning activities perspective: relationships among genders, learning styles, perceptions, and learning interest. International Journal of Mobile Learning and Organisation, 12(1), 55-76. https://doi.org/10.1504/JMLO.2018.089237.

Komalawardhana, N., Panjaburee, P., \& Srisawasdi, N. (2021). A mobile game-based learning system with personalised conceptual level and mastery learning approach to promoting students' learning perceptions and achievements. International Journal of Mobile Learning and Organisation, 15(1), 29-49. https://doi.org/10.1504/IJMLO.2021.111596.

Kurz, T. L., \& Batarelo, I. (2010). Constructive features of video cases to be used in teacher education. TechTrends, 54(5), 46-53.

Lederman, N. G., Antink, A., \& Bartos, S. (2014). Nature of science, scientific inquiry, and socio-scientific issues arising from genetics: a pathway to developing a scientifically literate citizenry. Science \& Education, 23(2), 285-302. https://doi.org/1 0.1007/s11191-012-9503-3.

Levin, B. B. (1995). Using the case method in teacher education: the role of discussion and experience in teachers' thinking about cases. Teaching and Teacher Education, 11(1), 63-79. https://doi.org/10.1016/0742-051X(94)00013-V.

Lokayut, J., \& Srisawasdi, N. (2014). Designing educational computer game for human circulatory system: A pilot study. In Liu, C.-C. et al. (Eds.), Proceedings of the 22 International Conference on Computers in Education (pp. 571-578). Japan: AsiaPacific Society for Computers in Education.

Mayer, R. E. (2009). Constructivism as a theory of learning versus constructivism as a prescription for instruction. In S. Tobias \& T. M. Duffy (Eds.), Constructivist instruction: Success or failure? (pp. 184-200). Routledge: Taylor \& Francis Group.

McLarty, K., Goodman, J., Risko, V., Kinzer, C. K., Vye, N., Rowe, D., \& Carson, J. (1990). Implementing anchored instruction: Guiding principles for curriculum development. In J. Zutell \& S. McCormick (Eds.), Literacy theory and research: Analyses from multiple paradigms (pp. 109-120). Chicago, IL: National Reading Conference.

McQuiggan, S., Kosturko, L., McQuiggan, J., \& Sabourin, J. (2015). Mobile learning: a handbook for developers, educators, and learners. Hoboken, NJ: Wiley.

Meekaew, N., \& Ketpichainarong, W. (2018). An augmented reality to support mobile game-based learning in science museum on biodiversity. In Proceedings of 7 th International Congress on Advanced Applied Informatics (IIAl-AAI), (pp. 250-255). Japan: International Institute of Applied Informatics. https://doi.org/10.1109/IAI-AAl.2018.00055.

Mishra, P., \& Koehler, M. J. (2006). Technological pedagogical content knowledge: a framework for teacher knowledge. Teachers College Record, 108(6), 1017-1054. https://doi.org/10.1111/j.1467-9620.2006.00684.x.

Momypedia, M. (2013). The computer game affliction, game addition: crisis situation of Thai children. Momypedia, 2556(June).

Newhouse, C. P., William, P. J., \& Pearson, J. (2006). Supporting mobile education for pre-service teachers. Australasian Journal of Educational Technology, 22(3), 289-311.

Niess, M. L. (2005). Preparing teachers to teach science and mathematics with technology: developing a technology pedagogical content knowledge. Teaching and Teacher Education, 21(5), 509-523. https://doi.org/1 0.1016/j.tate.2005.03.006.

Niess, M. L., Ronau, R. N., Shafer, K. G., Driskell, S. O., Harper, S. R., Johnston, C., \& Kersaint, G. (2009). Mathematics teacher TPACK standards and development model. Contemporary Issues in Technology and Teacher Education, 9(1), 4-24.

Niess, M. L., Lee, K., Sadri, P., \& Suharwoto, G. (2006). Guiding inservice mathematics teachers in developing a technology pedagogical knowledge (TPCK). A paper presented at the American Education Research Association Annual Conference ( $p p$. 1-22). San Francisco, CA: AERA. Retrieved from http://eusesconsortium.org/docs/AERA_paper.pdf.

Rovegno, I., \& Dolly, J. (2006). Constructivist perspectives on learning. In D. Kirk, D. Macdonald, \& M. O'Sullivan (Eds.), The handbook of physical education, (pp. 242-261). Thousand Oaks, CA: Sage. https://doi.org/10.4135/9781848608009.n14.

Şad, S. N., \& Goktaş, O. (2014). Preservice teachers' perceptions about using mobile phones and laptops in education as mobile learning tools. British Journal of Educational Technology, 45(4), 606-618. https://doi.org/10.1111/bjet.12064.

Sahin, S. (2012). Pre-service teachers' perspectives of the diffusion of information and communications technologies (ICTs) and the effect of casebased discussions (CBDs). Computers \& Education, 59, 1089-1098.

Saltan, F. (2017). Online case-based learning design for facilitating classroom teachers' development of technological, pedagogical, and content knowledge. European Journal of Contemporary Education, 6(2), 308-316.

Schmitz, B., Klemke, R., Walhout, J., \& Specht, M. (2015). Attuning a mobile simulation game for school children using a design-based research approach. Computer \& Education, 81, 35-48.

Scott, A., Downton, A., Gronn, D., \& Staples, A. (2008). Engagement versus deep mathematical understanding: An early career teacher's use of ICT in a lesson. In M. Goos, R. Brown, \& K. Maka (Eds), Navigating currents and charting directions: Proceedings of the 31st annual conference of the Mathematics Education Research Group of Australasia (pp. 43-49). Brisbane, QLD: MERGA.

Shin, T. S., Koehler, M. J., Mishra, P., Schmidt, D. A. Baran, E., \& Thompson, A. D. (2009). Changing Technological Pedagogical Content Knowledge (TPACK) through course experiences. In I. Gibson, R. Weber, K. McFerrin, R. Carlsen, \& D. A. Willis (Eds. ), Society for Information Technology and Teacher Education International Conference book (pp. 4152-4156). Chesaoeake, VA: Association for the Advancement in Education (AACE).

Shulman, L. S. (1986). Those who understand: knowledge growth in teaching. Educational Researcher, 15(2), 4-14. https://doi. org/10.3102/0013189X015002004.

Smarkola, C. (2008). Efficacy of a planned behavior model: Beliefs that contribute to computer usage intentions of student teachers and experienced teachers. Computers in Human Behavior, 24(3), 1196-1215. https://doi.org/10.101 6/j.chb.2007.04.005. 
Srisawasdi, N. (2012). Student teachers' perceptions of computerized laboratory practice for science teaching: a comparative analysis. Procedia - Social and Behavioral Sciences, 46, 4031-4038. https://doi.org/10.1016/j.sbspro.2012.06.192.

Srisawasdi, N. (2014). Developing technological pedagogical content knowledge in using computerized science laboratory environment: An arrangement for science teacher education program. Research and Practice in Technology Enhanced Learning, 9(1), 123-143.

Srisawasdi, N., Kongpet, K., Muensechai, K., Feungchan, W., \& Panjaburee, P. (2016). The study on integrating visualized simulation into context-aware ubiquitous learning activities for elementary science education. International Journal of Mobile Learning and Organization, 10(4), 263-291. https://doi.org/10.1504/JMLO.2016.079502.

Srisawasdi, N., \& Panjaburee, P. (2014). Technology-enhanced learning in science, technology, and mathematics education: results on supporting student learning. Procedia - Social and Behavioral Sciences, 116, 946-950. https://doi.org/10.1016/j. sbspro.2014.01.325.

Srisawasdi, N., \& Panjaburee, P. (2019). Implementation of game-transformed inquiry-based learning to promote the understanding of and motivation to learn chemistry. Journal of Science Education and Technology, 28(2), 152-164. https:// doi.org/10.1007/s10956-018-9754-0.

Srisawasdi, N., Pondee, P., \& Bunterm, T. (2018). Preparing pre-service teachers to integrate mobile technology into science laboratory learning: an evaluation of technology-integrated pedagogy module. International Journal of Mobile Learning and Organization, 12(1), 1-17. https://doi.org/10.1504/JMLO.2018.089239.

Sung, H.-Y., \& Hwang, G.J. (2017). Facilitating effective digital game-based learning behaviors and learning performances of students based on a collaborative knowledge construction strategy. Interactive Learning Environments, 26(1), 1-17.

Sung, H.-Y., Hwang, G.-J., Wu, P.-H., \& Lin, D.-Q. (2018). Facilitating deep-strategy behaviors and positive learning performances in science inquiry activities with a 3D experimential gaming approach. Interactive Learning Environments, 26(8), 10531073.

Sutton, S. R. (2011). The preservice technology training experiences of novice teachers. Journal of Digital Learning in Teacher Education, 28(1),39-47.

Thomas, K. M., O'Bannon, B. W., \& Britt, V. G. (2014). Standing in the schoolhouse door: teacher perceptions of mobile phones in the classroom. Journal of Research on Technology in Education, 46(4), 373-395. https://doi.org/10.1080/15391523.2014. 925686.

Thompson, A., \& Mishra, P. (2007). Breaking news: TPCK becomes TPACK. Journal of Computing in Teacher Education, 24(2), 38-64.

Troussas, C., Krouska, A., \& Sgouropoulou, C. (2020). Collaboration and fuzzy-modeled personalization for mobile game-based learning in higher education. Computers \& Education, 144, 1-18.

Tsai, C.-C., Chai, C. S., Wong, B., Hong, H.-Y., \& Tan, S. C. (2013). Positioning design epistemology and its applications in education technology. Educational Technology \& Society, 16(2), 81-90.

Tsai, Y.-L., \& Tsai, C.-C. (2020). A meta-analysis of research on digital game-based science learning. Journal of Computer Assisted Learning, 36(3), 280-294.

Vate-U-Lan, P. (2015). Transforming classrooms through game-based learning: a feasibility study in a developing country. International Journal of Game-Based Learning, 5(1), 46-57. https://doi.org/10.4018/ijgbl.2015010104.

Voogt, J., Erstad, O., Dede, C., \& Mishra, P. (2013). Challenges to learning and schooling in the digital networked world of the 21st century. Journal of Computer Assisted Learning, 29(5), 403-413.

Willermark, S. (2017). Technological pedagogical and content knowledge: a review of empirical studies published from 2011 to 2016. Journal of Educational Computing Research, 56(3), 315-343.

William, B. (2005). Case based learning - a review of the literature: Is there scope for this educational paradigm in prehospital education?. Emergency Medicine Journal, 22(8), 577-581.

Zhang, J., Hong, H.-Y., Scardamalia, M., Teo, C. L., \& Morley, E. A. (2011). Sustaining knowledge building as a principle-based innovation at an elementary school. Journal of the Learning Sciences, 20(2), 262-307.

\section{Publisher's Note}

Springer Nature remains neutral with regard to jurisdictional claims in published maps and institutional affiliations.

\section{Submit your manuscript to a SpringerOpen ${ }^{\circ}$ journal and benefit from:}

- Convenient online submission

- Rigorous peer review

- Open access: articles freely available online

High visibility within the field

- Retaining the copyright to your article

Submit your next manuscript at $\boldsymbol{\nabla}$ springeropen.com 